Whitewashing the Movies 



\section{Whitewashing the Movies}

Asian Erasure and White Subjectivity in U.S. Film Culture

DAVID C. $\mathrm{OH}$

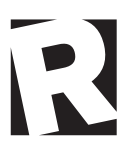

Rutgers University Press

New Brunswick, Camden, and Newark, New Jersey, and London 
Library of Congress Cataloging-in-Publication Data

Names: Oh, David C., author.

Title: Whitewashing the movies: Asian erasure and white subjectivity in U.S. film culture /

David C. Oh.

Description: New Brunswick: Rutgers University Press, [202I] | Includes bibliographical references and index.

Identifiers: LCCN 2020040334 | ISBN 9781978808621 (paperback) | ISBN 9781978808638 (hardcover) | ISBN 9781978808645 (epub) | ISBN 9781978808652 (mobi)|

ISBN 9781978808669 (pdf)

Subjects: LCSH: Asian Americans in motion pictures. | Whites in motion pictures. |

Ethnicity in motion pictures. | Motion pictures-United States-History-2oth century. |

Motion pictures-United States-History-2ist century.

Classification: LCC PNi995.9.A78 O43 | DDC 791.43/6529957-dc23

LC record available at https://lccn.loc.gov/2020040334

A British Cataloging-in-Publication record for this book is available from the British Library.

Copyright (C) 2022 by David C. Oh

All rights reserved

No part of this book may be reproduced or utilized in any form or by any means, electronic or mechanical, or by any information storage and retrieval system, without written permission from the publisher. Please contact Rutgers University Press, Io6 Somerset Street, New Brunswick, NJ 0890 . The only exception to this prohibition is "fair use" as defined by U.S. copyright law.

$\ominus$ The paper used in this publication meets the requirements of the American National Standard for Information Sciences-Permanence of Paper for Printed Library Materials, ANSI Z39.48-1992.

www.rutgersuniversitypress.org

Manufactured in the United States of America 
This book is dedicated to my partner, Eunyoung, and my children, Noah and Aaron. 
